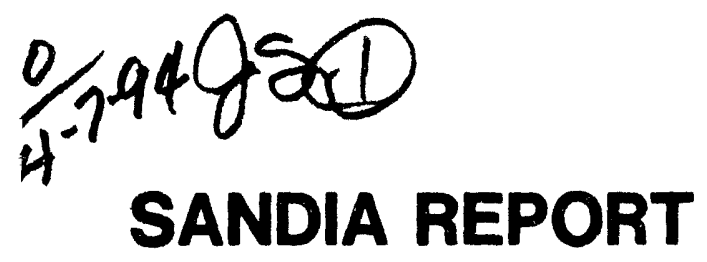

SAND93-2498 $\cdot$ UC -250

Unlimited Release

Printed March 1994

\title{
An Assessment of Leadership in Geothermal Energy Technology Research and Development
}

Vicki L. Bruch

Propored by

Eandla National Laboratoribe

Albuquerque, Now Moxlco 87185 and Llvermore, Callfornia 94550

for the United states Department of Energy

under Contract DE-ACO4-04ALEs000

Approved for public releace; diatritution is unlimited. 
Issued by Sandia National Laboratories, operated for the United States Department of Energy by Sandia Corporation.

NOTICE: This report was prepared as an account of work sponsored by an agency of the United States Government. Neither the United States Government nor any agency thereof, nor any of their employees, nor any of their contractors, subcontractors, or their employees, makes any warranty, express or implied, or assumes any legal liability or responsibility for the accuracy, completeness, or usefulness of any information, apparatus, product, or process disclosed, or represents that its use would not infringe privately owned rights. Reference herein to any specific commercial product, process, or service by trade name, trademark, manufacturer, or otherwise, does not necessarily constitute or imply its endorsement, recommendation, or favoring by the United States Government, any agency thereof or any of their contractors or subcontractors. The views and opinions expressed herein do not necessarily state or reflect those of the United States Government, any agency thereof or any of their contractors.

Printed in the United States of America. This report has been reproduced directly from the best available copy.

Available to DOE and DOE contractors from Office of Scientific and Technical Information PO Box 62

Oak Ridge, TN 37831

Prices available from (615) 576-8401, FTS 626-8401

Available to the public from

National Technical Information Service

US Department of Commerce

5285 Port Royal Rd

Springfield, VA 22161

NTIS price codes

Printed copy: A03

Microfiche copy: A01 


\title{
AN ASSESSMENT OF \\ LEADERSHIP IN GEOTHERMAL ENERGY TECHNOLOGY RESEARCH AND DEVELOPMENT
}

\author{
Vicki L. Bruch \\ Strategic Technologies Department \\ Sandia National Laboratories \\ Albuquerque, NM 87185
}

\begin{abstract}
Geothermal energy is one of the more promising renewable energy technologies because it is environmentally benign and, unlike most renewable energy sources, can provide base power. This report provides an assessment of the research and development (R\&D) work underway in geothermal energy in the following countries: Denmark, France, Germany, Italy, Japan, Russia, and the United Kingdom. While the R\&D work underway in the US exceeds the R\&D efforts of the other countries, the lead is eroding. This erosion is due to reductions in federal government funding for geothermal energy R\&D and the decline of the US petroleum industry. This erosion of R\&D leadership is hindering commercialization of US geothermal energy products and services. In comparison, the study countries are promoting the commercialization of their geothermal energy products and services. As a result, some of these countries, in particular Japan, will probably have the largest share of the global market for geothermal energy products and services; these products and services being targeted toward the developing countries (the largest market for geothermal energy).
\end{abstract}




\section{AN ASSESSMENT OF \\ LEADERSHIP IN \\ GEOTHERMAL ENERGY \\ TECHNOLOGY \\ RESEARCH AND DEVELOPMENT1}

\section{EXECUTIVE SUMMARY}

This report presents a review of geothermal energy technology research and development (R\&D) programs underway in selected countries, focusing on electricity generation. Specifically the report reviews who the leaders are in geothermal energy and how the work underway in the United States (US) compares to work being done in other countries. Leadership is defined according to the following criteria:

- how far the R\&D work has progressed (for example, demonstration stage versus data collection stage),

- how much money the government devotes to developing these technologies and whether funding level is consistent,

- how much R\&D work the country is actually doing in comparison to R\&D work being done in other countries,

- the efficiencies (economic and conversion) achieved.

The US is currently the leader in geothermal energy R\&D, but that lead is eroding due to declining government funding on geothermal energy technology R\&D and the decline of the US petroleum industry. R\&D work on one geothermal energy technology, hot dry rock, has stopped in the US due to lack of funding. The Japanese and Europeans are continuing major efforts in this area.

\footnotetext{
1This position paper was part of a study covering several emerging energy technologies. The study was conducted at the request of the Office of Foreign Intelligence, Office of Intelligence at the Department of Energy. Numerous unclassified intelligence sources and open source documents available as of October 1, 1993, were used. In addition to written materials, numerous interviews with technical experts were conducted. The interviews represented a cross section viewpoint from the national laboratories, government, academia, and industry. The conclusions presented here are those of the author.
} 
The largest market for future geothermal energy exploitation is in the developing countries because of good geothermal resources and the expected large increase in electricity demand. Although US firms have been successful in the past in dominating the geothermal energy market, competition among US, Japanese, and European firms is intense. Foreign governments are assisting their firms in obtaining the rights to develop geothermal resources in developing countries with such devices as tied donor aid. 2

The market for geothermal energy is not as great in the developed world due to the predominant use of conventional fuels. Geothermal energy is currently not cost-competitive with oil or natural gas in many developed countries. New directions in energy policies should improve the outlook for geothermal energy in many developed countries.

Efforts are underway in foreign countries which could be beneficial to US R\&D activities. Cooperative agreements with other nations could benefit the US in terms of cost and technology sharing. Drilling is a major activity in exploiting a geothermal reservoir, and the Russians and Germans are experienced in drilling deep wells. A collaborative effort with either or both of these two countries could be useful for both the US and the other country. Since the US has stopped hot dry rock development, agreements with the Japanese and Europeans would be in order to ensure that the US continues to have an active role in developing this technology.

Several of the technologies used in geothermal energy, such as drilling and reservoir modeling, are crosscutting technologies. As such, these technologies are applicable to other industries, including the petroleum and mining industries. Maintaining the US lead in developing geothermal technologies and ensuring that US industry has access to the applicable crosscutting technologies is important in ensuring that the US is competitive within the global energy arena.

The technical problems in developing hydrothermal geothermal energy are concerned with the expansion of proven hydrothermal resources. Improved technologies are needed in order to better define the base of available of hydrothermal resources. These technologies can also aid

\footnotetext{
2Tied donor aid is when a donor country will tie its foreign assistance programs to the use of the donor country's technologies, equipment, and/or personnel.
} 
in improving the cost-competitiveness of developing and using geothermal energy. Technical problems also exist in developing hot dry rock geothermal energy. Particular problems in this area include developing drilling technoiogies that can handle high temperatures and hard formations, a better understanding of the fracturing of the rock, and information regarding the reservoir itself (what flow rates are possible, reservoir characterization, etc.). Additional information is also needed regarding the cost-competitiveness of developing and using hot dry rock geothermal energy. Appendix A describes the various types of geothermal energy, including hot dry rock and hydrothermal.

\subsection{MARKET POTENTIAL}

The worldwide use of geothermal energy is expected to more than double by the year 2000 as emphasis on more environmentally benign energy technologies increases. In 1989, 6,000 megawatts $(\mathrm{MW})$ of geothermal electric power and $11,500 \mathrm{MW}$ of geothermal heating were installed throughout the world. It is estimated that by the year 2000, these figures will increase tc $15,000 \mathrm{MW}$ of geothermal electric power and $23,000 \mathrm{MW}$ of geothermal heating [1]. However, electricity generated by geothermal energy is small compared to total world electricity capacity. In 1989, total world installed electricity capacity was 2.6 million MW (0.2 percent provided by geothermal energy) [2].

Much of the growth in geothermal energy use is expected in the developing countries. Many of these countries lie along the world's main geothermal zones and have good geothermal resources, in particular, the Pacific Rim nations, Central America, the Caribbean islands, and the countries along the west coast of South America. These countries are also expected to have large growth rates in electricity demand. Sirce many of the developing countries must pay high prices for their imported fuel, geothermal energy is cost-competitive with other fuels. The use of indigenous geothermal energy can also reduce the outflow of needed hard currency to foreign energy suppliers.

Geothermal energy plays a key role in the energy policies of several developing nations. For example, Mexico and Indonesia are both oil producers and have good geothermal resources. They are encouraging development of their geothermal resources in order to reduce their internal consumption of oil and natural gas. Oil and natural gas exports can therefore be maintained, bringing in needed foreign currency. 
The market potential for geothermal energy is not as strong in the developed countries. In developed countries, such as the US, oil and natural gas are direct competitors of geothermal energy. Presently, in most cases (with the exception of The Geysers field in northern Califomia and Lardarello in Italy), geothermal energy is not cost-competitive with either oil or natural gas. New directions in energy policy, such as the inclusion of externalities in the price of a fuel and carbon dioxide taxes, should increase the cost-competitiveness of geothermal energy. Specifically in the US, the Clean Air Act Amendments and the Energy Policy Act of 1992 (EPAct) should improve the market potential for geothermal energy. The EPAct authorizes the Department of Energy (DOE) to oversee joint venture projects between government and private industry which focus on the demonstration and commercialization of renewable energy, including geothermal. In addition, the DOE may now enter into agreements with private lenders to pay a portion of the interest on loans for renewable energy projects.

Since the largest potential market for geothermal energy exists in the developing countries, the leading countries in geothermal energy technology $R \& D$ are particularly interested in exploiting the geothermal resources in these less developed countries (LDCs). Much of the geothermal energy work performed in the LDCs is conducted by institutions from these leading countries. The next section defines the concept of leadership in geothermal energy R\&D and identifies the leading countries.

\subsection{LEADERS IN GEOTHERMAL ENERGY R\&D}

According to geothermal energy experts, the following criteria are important in defining who is leading in geothermal energy technology R\&D:

- How far has the R\&D work progressed, for example, is the work in the demonstration stage or is it at the data collection stage?

- How much money is the government devoting to developing these technologies? Is the funding level consistent? Funding is not only an indication of leadership but also indicates the importance a country places on a technology.

- How much R\&D work is a country actually doing and is the country actually exploiting, that is extracting energy, from a resource?

- What are the achieved efficiencies (economic and conversion)? 
Based upon the criteria listed above, the leading countries in geothermal energy R\&D are as follows:

\section{US}

2. Italy

3. Japan

4. New Zealand

While the US is the clear leader among the four nations, experts in the field of geothermal energy have differing opinions with regard to the ranking of the remaining three countries. Many other countries are also involved in geothermal energy R\&D; however, their work is not of the caliber of the leading countries. Other countries researching and developing geothermal energy technologies include France, Germany, Iceland, Indonesia, the Philippines, Russia, and the United Kingdom (UK).

The US is particularly good at technologies which identify and capture geothermal energy while the Japanese are good at technologies which convert geothermal energy to power. Examples of technologies in which the US leads are reservoir characterization, modeling, exploration, and drilling. 3 Japan has the largest share of the global market for equipment required for geothermal power plants (turbines, steel pipe). Italy is also a strong player in the power plant equipment arena.

In hot dry rock technology, the Japanese and Europeans are approximately two years behind the United States. ${ }^{4}$ The European program is still in the early stages of collecting data while the Japanese are preparing for field tests on long-term flow rates. The US reached the demonstration stage and began conducting long-term flow tests at the facility at Los Alamos National Laboratory. However, Los Alamos recently announced the shut down of its hot dry rock project due to lack of funding. Future prospects for US government funding are not particularly encouraging and Los Alamos is searching for an industrial partner to help continue

3Note that these technologies all have roots in the petroleum industry.

${ }^{4}$ David V. Duchane, Program Manager, Hot Dry Rock Program, Los Alamos National Laboratory. Telephone interview with Vicki Bruch, March 19, 1993. 
the work [3]. The US appears to be relinquishing development of hot dry rock geothermal energy technology to the Europeans and Japanese. 5

As discussed earlier, one indication of leadership is funding devoted to R\&D. Figure 1 is a graph of government funding devoted to geothermal energy R\&D for the countries specified for this project.

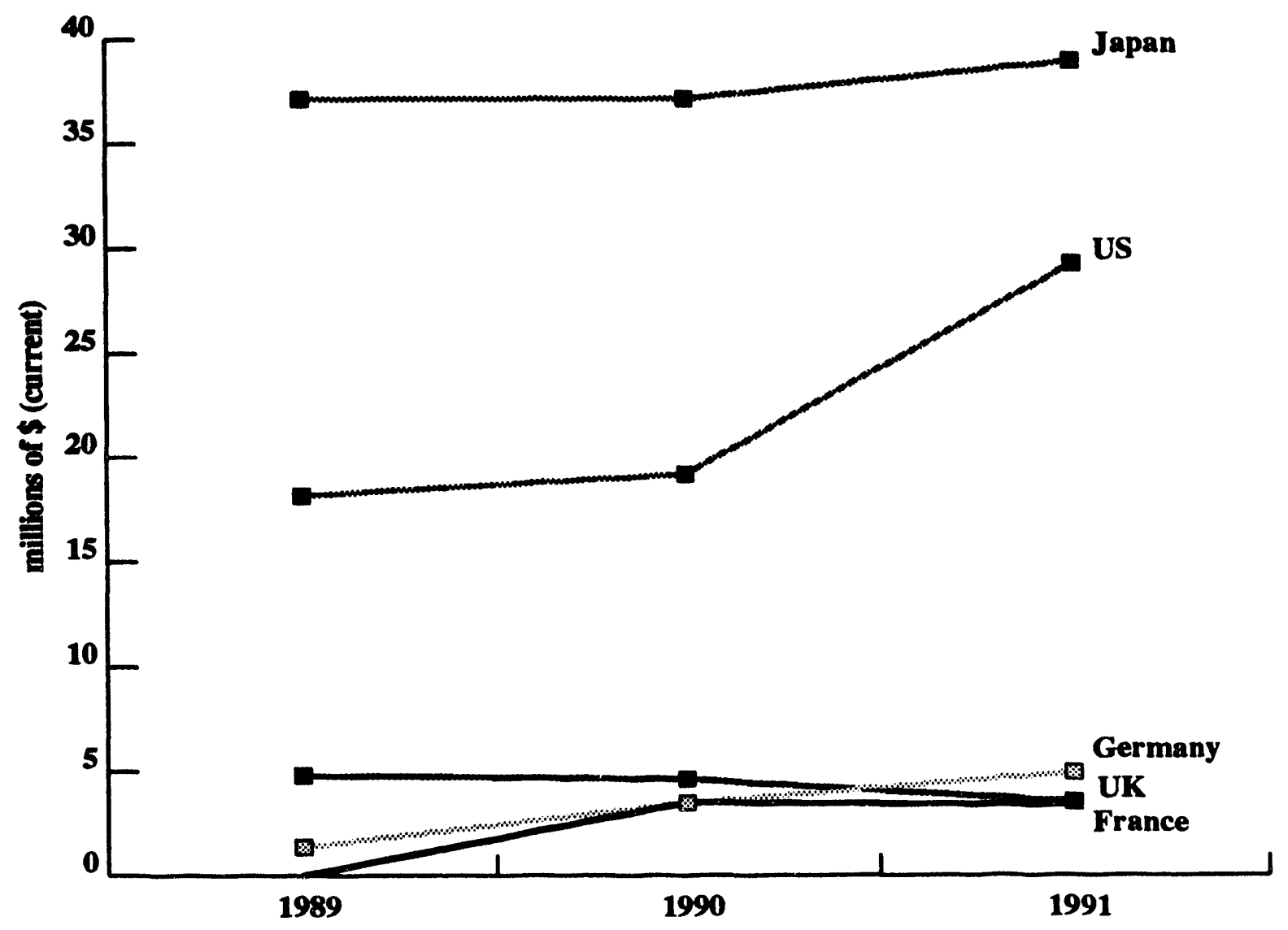

Note: Funding amounts could not be identified for Denmark, Italy, Russia, and for France for 1989.

Figure 1. Annual geothermal energy R\&D government funding for the study countries and the United States. Source: International Energy Agency, Paris, France, 1991 and 1992.

${ }^{5}$ Hot dry rock energy extraction, like many emerging energy technologies, was first investigated in the US in the early 1970 s. 
In reviewing Figure 1, it is clear that Japan leads in terms of funding for geothermal energy R\&D followed by the United States. However, these reported funding numbers may not be providing the entire story. For example, much of Germany's geothermal work is included in its budget for very deep drilling. It is believed that approximately $\$ 30-40$ million per year is spent on geothermal energy development in Germany. 6

The importance a country places on a technology can be determined by reviewing the amount of funding devoted to a particular technology over a number of years. In general, Japar and the European countries have provided a more stable and consistent level of funding and support for geothermal energy than the US, indicating they believe geothermal energy is a technology worth developing and commercializing. A consistent level of funding and support almost always results in $R \& D$ efforts superior to those $R \& D$ efforts resulting from an erratic funding schedule. This consistent level of support has helped the Europeans and Japanese erode the US lead in geothermal energy R\&D.

\subsection{GEOTHERMAL ENERGY R\&D ACTIVITIES OF STUDY COUNTRIES}

Geothermal energy R\&D work is underway at various levels in all the study countries (Denmark, France, Germany, Italy, Japan, Russia, and the UK). The largest efforts are in Italy and Japan due to their good geothermal resources and national policies which promote the development and use of geothermal energy. Brief descriptions of the geothermal energy R\&D activities underway in the individual countries for this study follow.

\subsection{DENMARK}

Little interest has been shown in Denmark for geothermal energy due to their lack of good geothermal resources. Work has concentrated to date on using geothermal energy for localized district heating, not for power generation. Heat pumps are used to extract energy from the brine in the geothermal reservoir. The European Community (EC) has provided some funding to Denmark for its heat pump plant. Dansk Olie og Naturgas AVS is the sole company exploiting geothermal energy in Denmark.

\footnotetext{
6Marshall J. Reed, Program Manager, Geothermal Reservoirs, US Department of Energy. Personal interview with Linda Branstetter, March 24, 1993.
} 


\subsection{FRANCE}

There is little work underway in France in geothermal energy R\&D due to the following:

- dominance of nuclear power in generating electricity,

- low cost of oil and natural gas compared to the cost of geothermal energy,

- poor geothermal resources,

- high cost of electricity generated from geothermal energy (particularly energy extracted from hot dry rock) due to the poor heat conversion efficiency.

The bulk of the geothermal energy work done in France involves localized district heating. Approximately 200,000 buildings use geothermally-produced heat. This work, which began in the 1960s, has slowed due to the decline in oil prices. France is involved in the hot dry rock project near Strasbourg which is sponsored by the EC. The project is in the early stages with work concentrating on understanding the geology of the sites. French institutions involved in this work are the University of Paris VII and the Bureau de Recherches Geologiques et Minieres.

\subsection{GERMANY}

Development of geothermal energy technologies in Germany lags when compared both to the work underway in other countries on geothermal energy and when compared to the work done in Germany on other renewable energy technologies. As a result, there is little practical experience in using geothermal energy in Germany. One reason there is little geothermal work in Germany is the lack of good high-temperature geothermal resources. The Germans must drill very deep to reach good geothermal resources. The Germans have a deep drilling program in southeastern Germany where a depth of 7.5 kilometers has been reached to date [4]. Although this program is primarily a scientific program on drilling technologies, the very deep drilling techniques being investigated could be useful in exploiting geothermal reservoirs. Funding for this Federal Research Ministry-sponsored program totals $\$ 312.5$ million [5]. It is believed that much of the budget for Germany's geothermal R\&D activities is included in the deep drilling budget.

A map of the geothermal energy installations in Germany is shown in Figure 2. 


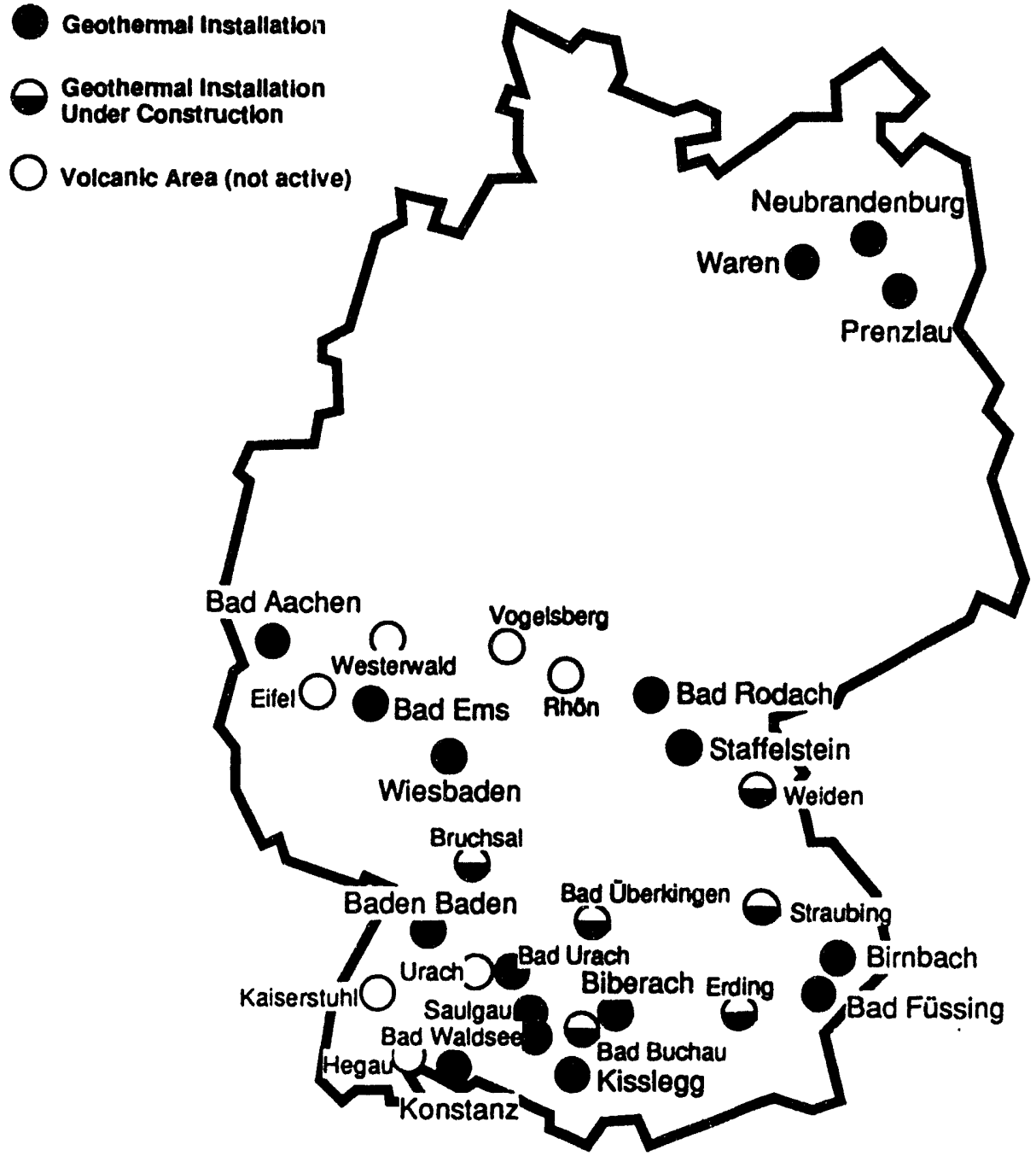

Figure 2. Geothermal energy installations in Germany.

The highest temperature geothermal geologic formations are located in southern Germany; therefore, it is this region where it is most economical and efficient to extract geothermal energy. There are, however, a few installations in the former East Germany which are also used for district heating. The geothermal activity in Germany is mainly limited to the use of heat pumps to provide heat to buildings.

Germany is collaborating with France on the EC-sponsored hot dry rock project at Strasbourg, France. The project is in the data collecting stage with the University of Karlsruhe as the major German participant. It appears this project is far behind the hot dry rock project that was recently terminated in the United States. 


\subsection{ITALY}

Italian national energy policy considers developing Italy's geothermal resources a major activity. Italy imports nearly all of its energy and imported energy costs are expected to rise in the future. Energy consumption is also expected to increase in the future. Italy considers geothermal energy an important asset because it is indigenous and environmentally benign. Most of the technology and equipment required to exploit Italy's geothermal resources are developed and available in Italy. Geothermal energy currently produces $600 \mathrm{MW}$ of electrical energy (1.5 to 2 percent of Italy's total energy consumption) [6]. A goal is to increase the installed capacity to $1,500 \mathrm{MW}$ by the year 2000 [7]. All of the work has involved hydrothermal resources.

ENEL, the Italian National Agency for Electrical Production, is responsible for developing Italy's geothermal resources. It is currently undergoing privatization. ENEL plans to spend \$2.44 billion during the 1990s to continue the development of geothermal sources for electricity production [7]. Approximately 1,500 people at ENEL work on geothermal energy technologies [8]. Agip, the Italian national oil company (also undergoing privatization) has been involved in geothermal energy for the past ten years. Privatization is expected to increase the competitiveness of these companies, particularly ENEL. Because these firms were not privately owned, profits were not of importance and the efficiency and cost-competitiveness of the companies often lagged when compared to privately owned firms. Furthermore, ENEL tended to downplay foreign markets in the past. That will rrobably change as ENEL and Agip strive to increase profits and compete against private US, Japanese, and European companies.

ENEL is planning a major upgrade at the Larderello geothermal power station, the first power station in the world to generate electricity from geothermal energy. The plan is to add five new plants which will more than double the total output from Larderello by the year 2000 [8]. New techniques, such as horizontal drilling (developed by the petroleum inciustry), are allowing several different geothermal fields to be tapped into and connected, increasing the output of the power plant.

Work is also underway to exploit low-temperature geothermal reservoirs. These reservoirs will be used for agricultural purposes and district heating. Much of this work is being 
performed in universities: University of Bari, University of Trieste, and the University of Genoa.

\subsection{JAPAN}

Geothermal energy development is a key part of Japan's energy policy because it is one of the few indigenous sources of energy for Japan, which imports nearly all of its energy resources. Japan has good geothermal resources with over $\mathbf{2 0 0}$ geothermal fields. It is estimated that Japan possesses $10 \%$ of the world's potential geothermal energy [9].

Despite having enormous potential, Japanese geothermal resources could be viewed as underdeveloped. In 1992, ten geothermal power plants were in operation producing $271 \mathrm{MW}$ of power [10], ranking Japan only sixth in geothermal electric power capacity world wide [11]. Japan's geothermal resources have not been fully exploited because public opinion for geothermal energy is not strong. There is resistance to building geothermal power plants because many potential sites are located near national parks. Also, there is concern the geothermal power plants will diminish the amount of hot water available to spas. As a result, Japan has set a rather modest goal to increase in-country power production from geothermal energy to $1,000 \mathrm{MW}$ by the year 2000 [12].

The Japanese government has provided some support to the private sector to develop geothermal resources. Cost and interest subsidies are granted to companies drilling new wells. Subsidies are also provided for the construction of new geothermal plants. There is a partial exemption of national and local taxes for private power generating plants.

The Japanese are focusing on export markets for their geothermal energy technologies because of the limited appeal for geothermal energy in Japan. Japan already has the largest share of the global market for geothermal power plant equipment. The Japanese government is increasing its efforts in hot dry rock $R \& D$ to enhance the commercialization and export prospects of this technology.

Efforts to develop hot dry rock geothermal energy are progressing faster in Japan than in any other country [13]. Work is underway at three sites in Japan compared to the one site in the US. Currently, Japan spends approximately $\$ 8$ million per year on hot dry rock R\&D and a 
working hot dry rock power plant should be in place at one of the Japanese sites by 1996 or 1997 [13]. The Japanese are exploring some rather innovative ideas, such as the concept of creating several hot dry rock reservoirs at different depths in a single well to minimize drilling costs [14].

Research efforts are also underway in hydrothermal geothermal energy. R\&D work in hydrothermal energy includes developing binary cycle power generation plants, implementing reservoir evaluation techniques, and designing/constructing pumps that can withstand high water temperatures. New drilling-related technologies that are being developed include improved drill bits that can drill through hard formations, improved methods which minimize lost circulation problems associated with drilling, and improved materials for drilling equipment. These technologies are important crosscutting technologies that have applications in other fields such as petroleum exploration and development, thereby potentially providing new market opportunities for Japanese firms.

NEDO (New Energy and Industrial Technology Development Organization) is developing a comprehensive geothermal resource analysis system to help identify potential geothermal energy development sites. A major effort in this program is a six-year project, begun in 1992, to exploit untapped geothermal reservoirs which lie deeper than 2,000 meters underground. The goal of this effort is to make deeper sources of geothermal energy more practical and adaptable. Private industry is assisting NEDO in this effort [15].

Japan considers geothermal energy an important source of energy that should be developed and exploited, both in the domestic and particularly in foreign markets. An indication of how important the development of geothermal energy is to Japan is shown in Figure 3, Japanese government funding for renewable energies in 1991. 


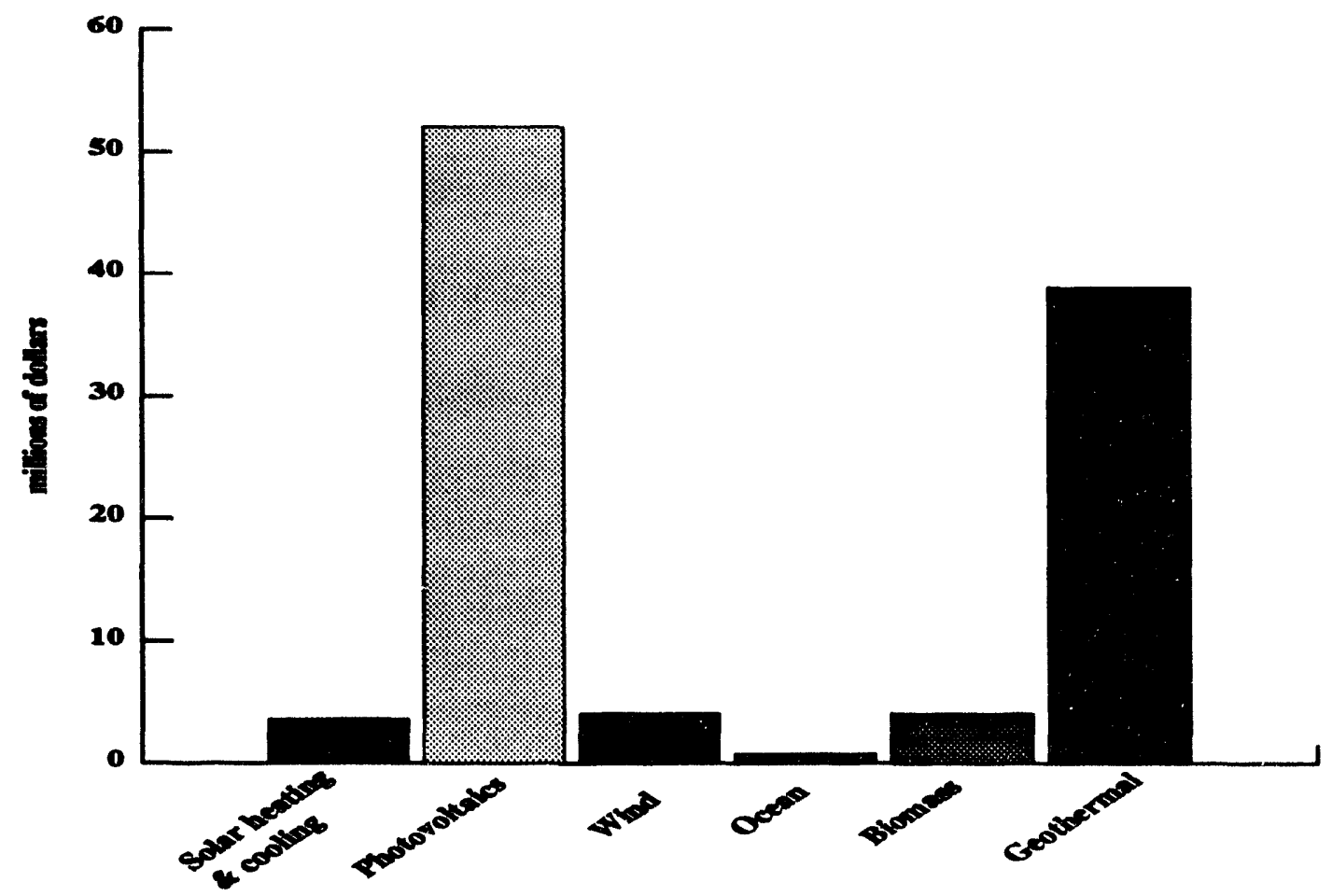

Figure 3. Japanese government funding for renewable energies in 1991.

Source: Energy Policies of IEA Countries: 1991 Review, (Paris: OECD/IEA, 1992), 544.

Geothermal is second only to photovoltaics in terms of the amount of funding the Japanese devote to the various renewable energy $R \& D$ sectors.

Geothermal energy R\&D work in Japan is directed by NEDO. It works to coordinate the funds, personnel and technological strengths of both the public and private sectors. Although this government agency plays the leading role, private industry and universities are also heavily involved in the research efforts, as well as other government agencies. The Agency of Natural Resources and Energy assists in the drilling of wells. Mitsubishi Metal Corporation and the Central Research Institute of Electric Power Industry (CRIEPI) are major organizations in developing new technologies. Mitsubishi Heavy Industry and Toshiba dominate the world market for turbine sales for geothermal power plants. Tohoku University has launched a program to study hydraulic fracturing. Fujita Corporation, a construction company, explores and locates new geothermal sites for development. This list of Japanese organizations was 
included to demonstrate how intertwined the public and private sectors are in Japan. This close public-private sector cooperation can make it difficult for foreign firms to perform work and sell their technology and products in Japan.

\subsection{RUSSIA}

The situation in Russia regarding geothermal energy technology R\&D is unclear due to the confused and changing economic situation. Communication between US and Russian reseirchers is becoming increasingly difficult. It is known that geothermal power plants and systems are under construction. These facilities are all hydrothermal developments and are mainly used for space heating. The only operating geothermal power plant is the Pauzhetskaya operating station in Kamchatka. This power station has three units and, as of 1992, its operating capacity was projected to increase. The construction of a second larger geothermal power plant was underway in 1992 in the Mutnovskaya area in Kamchatka [16].

Russia has good geothermal resources, particularly on the Kamchatka peninsula. There has been some interest expressed in having US firms develop these resources. 7 The Russians have developed deep drilling techniques that could be applicable to geothermal energy exploration and development. They have drilled the world's deepest borehole on the Kola peninsula. 8

There is an active hot dry rock program in Russia although activity has declined since the dissolution of the Soviet Union. Six projects were originally planned; only the Tirniauz project in the Caucasus is underway. The hot dry rock projects were cut due to lack of funding and the fact that the projects ended up being located in different countries throughout the former Soviet Union. The Leningrad Mining Institute is responsible for hot dry rock R\&D work underway in Russia.

Hot dry rock R\&D work underway in Russia has in the past compared favorably to the work performed in the United States. Due to their lack of capital equipment, the Russians may have

7Dave Anderson, Executive Director, National Geothermal Association. Telephone interview with Vicki Bruch, March 23, 1993.

${ }^{8}$ At 12 kilometers, it is deeper than the borehole drilled by the Germans in their deep drilling project. 
analyzed the hot dry rock geothermal processes in greater detail than US scientists. Russia has asked the US for assistance in monitoring microseismic activity at the Tirniauz site, but no aid has been forthcoming [17].

\subsection{UNITED KINGDOM}

Work in the UK has focused on hot dry rock technology because there are limited hydrothermal resources in the UK. Government-sponsored work on hydrothermal energy development has stopped because of the lack of high-temperature geothermal resources. The only example of hydrothermal work underway in the UK is the district heating project in the Southampton City Center. This work began in 1988 and uses geothermal energy to provide heat to a number of buildings. Hot dry rock work is focused in the Cornwall area and has been underway for approximately 15 years.

The Camborne School of Mines is the lead institute for the hot dry rock work being done at Cornwall. According to US experts, the researchers at Camborne are considered leading experts in the manipulation of rock. The work at Camborne has concentrated much more on basic research than the work underway in the United States. The British Geological Survey is also involved in the hot dry rock project. Most of the funding for this project has come from the British government with some contributions from the EC and British industry.

Experiments performed at Cornwall thus far have been disappointing because of high water losses and short thermal lifetimes of the geothermal formations. The Cornwall site is located in a low-temperature area, which accounts for most of the disappointing results. Researchers have drilled down two kilometers and have been able to prove the basic principle of hot dry rock technology. However, it is believed hot dry rock will only become cost-effective in the UK if the wells are drilled six to eight kilometers deep.

In 1991, the British government decided to cease the hot dry rock field work at Cornwall and instead participate in the EC program at Strasbourg, France. The reemphasis in allocating R\&D resources was due to the high cost of exploiting hot dry rock geothermal resources, the long-term rather than short-term payoff for hot dry rock $R \& D$, and the realization that the difficult technical problems may be more readily resolved in collaboration with other European researchers. 


\subsection{EUROPEAN COMMUNITY (EC)}

EC R\&D programs aim to complement national programs and provide support for programs in generic areas. In the area of geothermal energy, the EC programs have accomplished the following:

- encouraged member countries to establish national geothermal programs,

- promoted cooperation between research teams in different countries,

- created a database of geothermal data from member countries relevant to developing geothermal resources.

The EC can provide up to 50 percent of the funding required for a project that would benefit the entire Community. Since 1975, the EC has devoted $\$ 4.4$ - 5.5 million annually to geothermal energy programs [18].

An example of an EC-sponsored collaborative program is the hot dry rock study underway in Strasbourg, France. The EC believes hot dry rock development is particularly suited to collaborative work because of the high costs involved and due to the magnitude of certain technical problems which may be solved more successfully through joint efforts among the R\&D establishments of various EC-member countries. A goal of the EC JOULE program is to prove the commercial feasibility of hot dry rock energy extraction. The EC is sponsoring another hot dry rock project which will be undertaken by a consortium of European industrial firms. The $\$ 300$ million, 10 year program is aimed at developing hot dry rock energy extraction in low temperature areas [19]. This is an example of a consistently-funded program; the type of program that can lead to commercial success.

The EC has also sponsored hydrothermal collaborative projects. The projects have occurred in Travale, Italy and Milos, Greece.9 Examples of generic geothermal studies sponsored by the EC address corrosion and scaling problems, new materials for piping systems, and drilling in hostile environments.

\footnotetext{
OThe Japanese firm, Mitsubishi, has also had a project on Milos island to develop that island's geothermal resources.
} 


\subsection{EXPLOITING THE R\&D POTENTIAL OF OTHER COUNTRIES}

Research and development work underway in the study countries could potentially be of benefit to US researchers. One tool that could be used to exploit the geothermal energy R\&D potential of these countries is a cooperative agreement between the US and another country. The benefits of a cooperative agreement include both cost-sharing and information-sharing. The cooperative agreement would also ensure the US maintains a presence in the geothermal energy technology market.

Cooperative agreements between the US and other countries have proved beneficial to the US in the past and should continue to be pursued. The DOE has had cooperative agreements in the past with Mexico and Italy on hydrothermal technologies and with Japan and Germany on hot dry rock technology. 10 The UK has expressed an interest in joint reservoir projects with the United States.

The cooperative agreement with the Japanese and Germans on hot dry rock technology occurred in the mid-1980s and was beneficial to all parties involved. Both the Japanese and Germans supplied funding and researchers to the project. The US gained from the financial contributions and knowledge from the foreign researchers. The current Japanese hot dry rock program has been heavily influenced by the work done under this cooperative agreement.11

The cooperative agreements with Mexico and Italy have not been as successful as the agreement with Japan and Germany. These agreements with Mexico and Italy have been in place for approximately 15 to 20 years but are essentially inactive because of the lack of funding for both the US and the other country. Mexico's interests are in implementing geothermal energy technologies; it has little funding to devote to R\&D of geothermal energy technologies. The cooperative agreement between the US and Mexico has generated good information regarding the geothermal fields near the US - Mexico border.

\footnotetext{
10James Dunn, Manager, Geothermal Research Department, Sandia National Laboratories. Personal interview with Vicki Bruch, March 16, 1993. David V. Duchane, Program Manager, Hot Dry Rock Program, Los Alamos National Laboratory. Telephone interview with Vicki Bruch, March 19, 1993.
}

11David V. Duchane, Program Manager, Hot Dry Rock Program, Los Alamos National Laboratory. Telephone interview with Vicki Bruch, March 19, 1993. 
Cooperative agreements between other countries and the US should be emphasized since the US has reduced its efforts in geothermal energy. Cooperative agreements will ensure that the US continues to have an active role in technology development while the sharing of costs with other countries will not exasperate the US budget deficit. Cooperative efforts should be explored with the Russians and Germans regarding deep drilling and hot dry rock technologies and with the Japanese and Europeans on hot dry rock technology. The Germans have expressed an interest in developing their deep drilling project into an international project [4]. In particular, experts in geothermal energy believe future cooperative agreements with Japan would be beneficial to the US because of the commitment Japan has to geothermal energy and the amount of resources it has devoted to geothermal energy R\&D.

\subsection{IMPLICATIONS FOR THE UNITED STATES}

Geothermal energy R\&D work underway in the different countries has the potential to surpass the R\&D work currently underway in the United States, increasing the importance of cooperative agreements. Although the US is now considered to be the leader in geothermal energy R\&D for both hydrothermal and hot dry rock, that lead is eroding. It is eroding for the following reasons:

- geothermal energy R\&D funding has been declining,

- US petroleum industry is in decline.

The US has devoted large sums of federal funding to geothermal energy R\&D although Japan now devotes more funding to geothermal energy R\&D than the United States (in 1991 Japan spent $\$ 38.94$ million versus $\$ 27.3$ million for the US). However, US funding has not been consistent over the years. Funding declined substantially in the early 1980 s and is only now beginning to increase. US DOE funding for geothermal energy R\&D is shown in Figure 4. The majority of the funding is provided to DOE's national laboratories. 


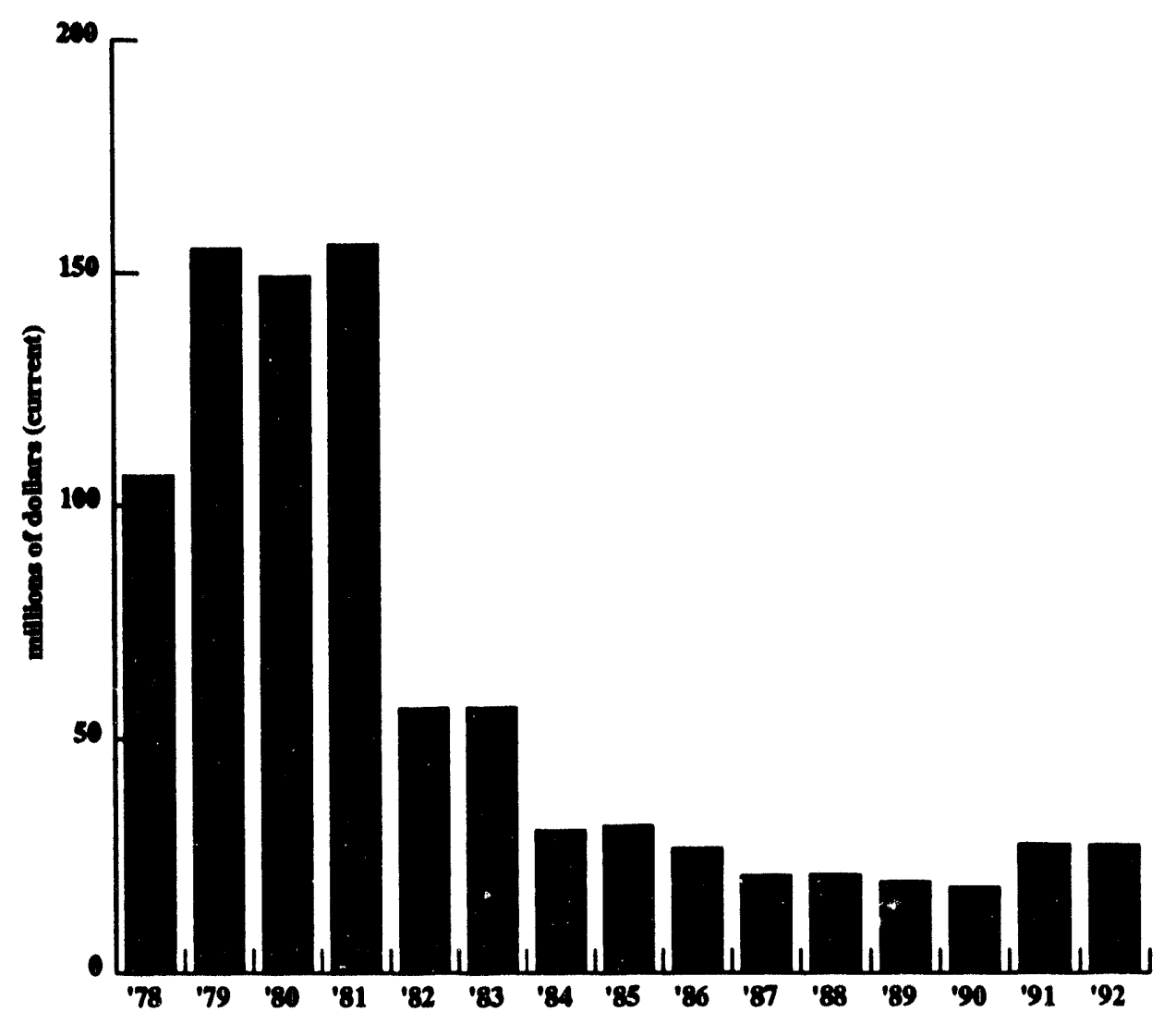

Figure 4. US DOE geothermal R\&D funding.

Source: Fred J. Sissine, Renewable Energy: A New National Commitment? Congressional Research Service Issues Brief, January 6, 1992.

As shown in Figure 4, geothermal energy R\&D funding in the US has undergone severe cutbacks, primarily due to the change in energy R\&D philosophy from the Carter Administration to the Reagan and Bush Administrations. Other countries have had some decline in their geothermal energy R\&D budgets but not to the extent of the US program.

Increased US government funding for geothermal energy R\&D does not appear likely. Without this continued support, commercialization of new geothermal energy extraction technologies becomes more difficult. The consistent level of support for geothermal energy provided by the Europeans and Japanese provides their scientists and engineers with a stable environment that is conducive to $R \& D$ breakthroughs. 
Another reason the US lead is eroding is the decline of the petroleum industry in the United States. Petroleum technologies and geothermal technologies have much in common; they are both involved in extracting energy or fuel from the earth. The strength of the US petroleum industry allowed for the development of geothermal energy technologies that could cost-effectively exploit geothermal resources. US petroleum companies have been active in geothermal development. For example, the US oil company UNOCAL has approximately $50 \%$ of the world market in terms of exploiting geothermal energy (this includes exploration, field development, and operations). 12 However, UNOCAL is currently restructuring and it is believed that their geothermal efforts will be negatively impacted by this restructuring. 13 Many US petroleum companies have undergone restructuring and have reduced R\&D budgets, both of which could negatively impact development of geothermal technologies in the United States. Funding for geothermal energy exploitation must compete with funding for oil and gas exploitation in US petroleum companies. Under current financial conditions, oil and gas exploitation usually wins.

While government and private industries in the US decrease their efforts in geothermal energy technologies, foreign governments and industries are increasing their activities in areas that could be applicable to geothermal energy. As an example. France and Germany are emphasizing drilling technologies and have increased funding in this area. They have decided that drilling technologies are key technologies for both the petroleum and geothermal industries and that additional R\&D work should be devoted to these technologies. Drilling costs are a major portion of the cost of exploiting geothermal resources.

Although the US continues to lead in geothermal energy R\&D, it lags in implementing the technologies. The Japanese and Europeans are much better at getting these technologies out into the marketplace. One reason for their success is government intervention. Examples of government intervention include subsidies and tied aid. In the past, the US government did not practice tied aid. The US is now considering implementing small amounts of tied aid to increase US economic competitiveness. Several US companies believe the use of tied aid by

12Marshall J. Reed, Program Manager, Geothermal Reservoirs, US Department of Energy. Personal interview with Linda Branstetter, March 24, 1993.

13 Carel Otue, retired President of Geothermal Division, UNOCAL. Telephone interview with Vicki Bruch, March i7, 1993. 
other countries is a major reason why US firms have difficulty competing with foreign firms, particularly in the LDCs. Provisions included in the Energy Policy Act of 1992, such as increased efforts in establishing government-private industry joint ventures, should help alleviate some of the tied aid problems faced by US companies. The US government can also provide other forms of assistance such as formal information exchanges among government agencies and industry, trade fairs, and identifying target opportunities in foreign countries for US firms.

US firms have had difficulties competing in the world energy market against Japanese firms in the past due to the exchange rate. The change in currency values should help the competitive position of the US against the Japanese and Europeans. However, the former high value of the dollar when compared against other currencies caused some US firms to leave the global geothermal energy market. For example, General Electric no longer produces turbines to be used in geothermal power plants. Some of these US firms have not returned to the geothermal energy market.

Currently, US industry plays a dominant role in the world market for geothermal energy technologies. However, that role is in danger of declining due to lack of funding and the decline and reorganization of the US oil industry. Both the EC and Japan are maintaining or increasing their efforts in geothermal energy R\&D. The end result may be that US industry will lose market share for geothermal energy technologies to its European and Japanese competitors.

\subsection{INTERVIEWS CONDUCTED}

The following individuals were interviewed by the author regarding issues of international technological competitiveness and markets. Additional interviews of Russian scientists and experts familiar with the Russian economic and political situation were conducted for the author by the Foreign Systems Research Center (FSRC) of Science Applications International Corporation (SAIC). Finally, the US/Japan Center at the University of New Mexico conducted interviews for the author of numerous contacts in the Japanese R\&D infrastructure and Japanese industry. 
Dave Anderson

Ronald DiPippo

David V. Duchane

James Dunn

Tom Hinrichs

Carel Otte

Marshall J. Reed

Jefferson Tester
Executive Director,

National Geothermal Association

Professor and Chairman, Mechanical Engineering Department, University of Massachusetts at Dartmouth

Program Manager, Hot Dry Rock Program,

Los Alamos National Laboratory

Manager, Geothermal Research Department, Sandia National Laboratories

Vice President of Government Affairs,

Magma Power Company

retired President of Geothermal Division,

UNOCAL

Program Manager, Geothermal Reservoirs, US Department of Energy

Director, Energy Laboratory,

Massachusetts Institute of Technology 


\section{References}

1. Palmerini, Civis G., "Geothermal Energy." Renewable Energy Sources for Fuels and Electricity, eds. Thomas B. Johansson, et al., Washington, DC, Island Press, 1993.

2. US Department of Energy, International Energy Annual 1990, Energy Information Administration, Washington, DC, January 1992.

3. "Los Alamos Lab Closes Jemez 'Hot Rock' Project," Albuquerque Journal, April 28, 1993.

4. "The Gang that Drilled Straight," Science, Vol. 261, July 16, 1993.

5. American Embassy, "STRIDE: Science and Technology News in Germany," Cable, Bonn, Germany, May 6, 1992.

6. American Embassy, "Italy Technology Round-Up, January - March 1993," Cable, Rome, Italy, March 17, 1993.

7. "Special Report: Italian Geothermal Energy," Financial Times European Energy Report, April 20, 1990.

8. American Consulate, "Energy Issues: A Case Study, Italy Expands Production of Geothermal Power," Cable, Florence, Italy, June 11, 1992.

9. Present State of Geothermal Energy Development, New Energy and Industrial Technology Development Organization, Geothermal Survey Department, Tokyo, Japan, March 1992.

10. Geothermal Energy Development Technology, New Energy and Industrial Technology Development Organization, Geothermal Energy Technology Department, Tokyo, Japan, February 1992. 
11. Atarashii Enerugi oh Tsukuru Creates New Energy, New Energy and Industrial Technology Development Organization, Tokyo, Japan, March 1991.

12. "MTII to Expand Aid to Promote Geothermal Power Generation," JPRS Report Science \& Technology: Japan, JPRS-JST-008L, February 8, 1993.

13. Batchelor, Anthony S., GeoScience Ltd. Written testimony for the House Subcommittee on Energy and the Environment, January 23, 1992.

14. Bower, Michael, "Geothermal Energy," Cool Energy: Renewable Solutions to Environmental Problems, Cambridge, MA, The MIT Press, 1992.

15. "New Developments in Japan's Geothermal Energy Program," Pacific Rim Economic Review, Vol. 2, No. 14, FBPSP93-014, July 14, 1993.

16. Bennicelli, Laura M., et al, Prospects for Russian Alternative Energy Development, Greenwood, CO, FSRC/SAIC, 1993.

17. Kruger, Paul, Stanford University. Testimony before the House Subcommittee on Energy and the Environment, January 23, 1992.

18. Garnish, J., E. Staroste, and K. Louwner, "Geothermal Research in the European Community," Geothermal Resources Council BULLETIN, March 1989.

19. Stevenson, Michael G. and David V. Duchane, Los Alamos National Laboratory. Testimony before the House Subcommittee on Energy and the Environment, January 23, 1992. 


\section{Appendix A \\ Technology Description}

Geothermal energy is naturally occurring heat present since the earth was formed and sustained by the radioactive elements inside the earth. It is rapidly gaining recognition as a renewable energy source with many advantages that can compete, in some locations, with conventional fuels. Unlike many other renewable sources of energy, geothermal energy can provide base load power. Geothermal power plants generally have higher on-line plant availabilities than either coal-fired plants or nuclear plants.

Geothermal energy is more environmentally benign than other sources of energy. Carbon dioxide emissions from geothermal energy power plants are typically less than five percent of those of a fossil fuel facility [1]. There are some geothermal energy environmental concerns such as noise from geothermal steam releases and subsidence caused by the removal of water from the ground. These concerns are mainly eliminated by operating practices (such as reinjection of ground water to avoid subsidence and the use of noise reduction equipment).

There are four types of geothermal energy sources:

$$
\begin{array}{ll}
\text { - } & \text { hydrothermal } \\
\text { - } & \text { hot dry rock } \\
\text { - } & \text { geopressured } \\
\text { - } & \text { magma }
\end{array}
$$

Each of these sources is briefly discussed.

\section{HYDROTHERMAL}

Hydrothermal reservoirs are formed when water is trapped in fractured rock or sediment below the Earth's crust. A high-temperature magma intrusion into the crust heats the water, turning it to steam or hot water [2]. A hydrothermal reservoir is shown in Figure A1. 

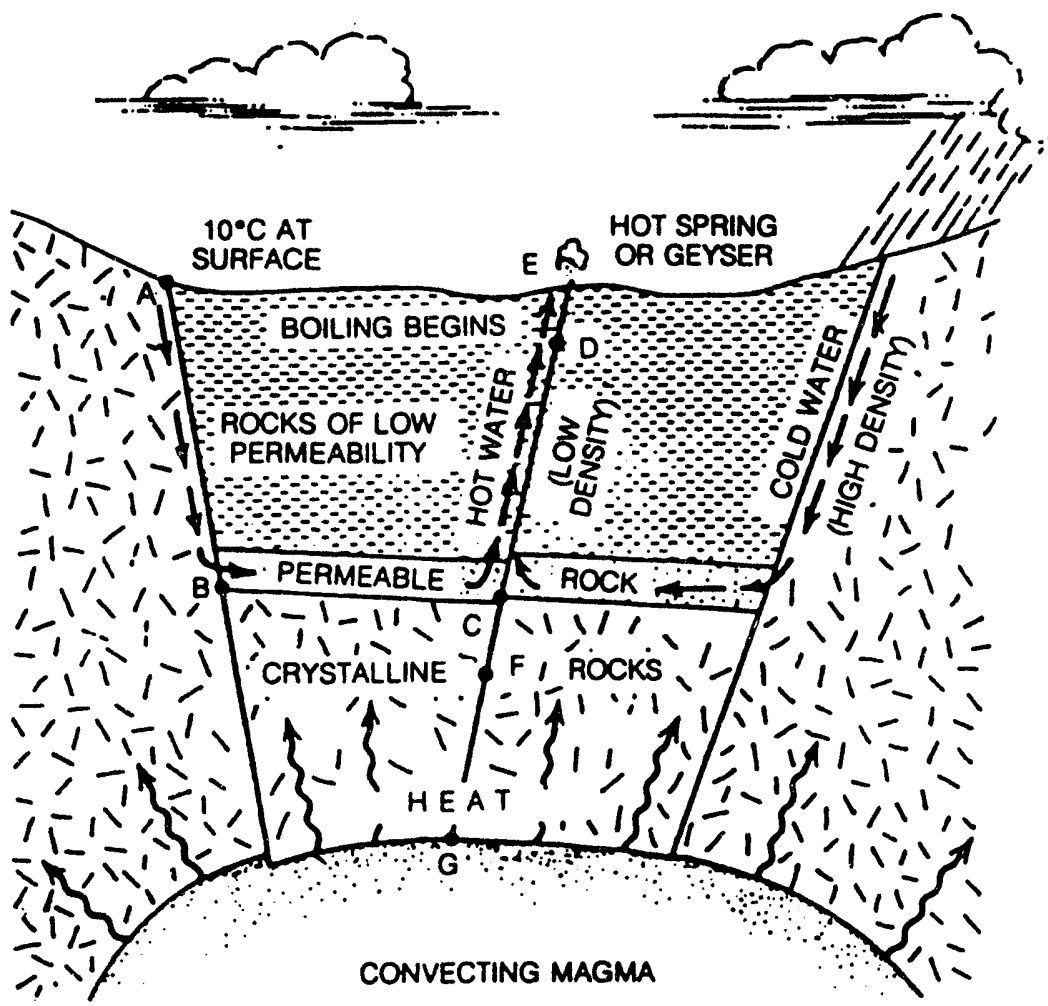

Figure A1. Diagram of a geothermal reservoir. Source: Renewable Energy: An Overview, US Department of Energy Information Brochure FS 175, (Washington, D.C.: US Department of Energy, March 1990).

The principal features of a hydrothermal reservoir are:

- heat provided by a magma intrusion,

- porous layer containing water above the intrusion,

- layer of low permeable rock which restricts the escape of the hot water and/or steam,

- fractures in the rock which allow some of the hydrothermal energy to escape to the surface. These fractures also allow recharge of the aquifer by rainwater seepage through the formations.

Hydrothermal reservoirs are characterized as either high-temperature brine or steam. The bulk of the reservoirs are brine. However, dry steam reservoirs are the easiest to use requiring no special equipment. Brine hydrothermal reservoirs require more extensive equipment. They require either a flash or a binary system. A binary system is shown in Figure A2. 


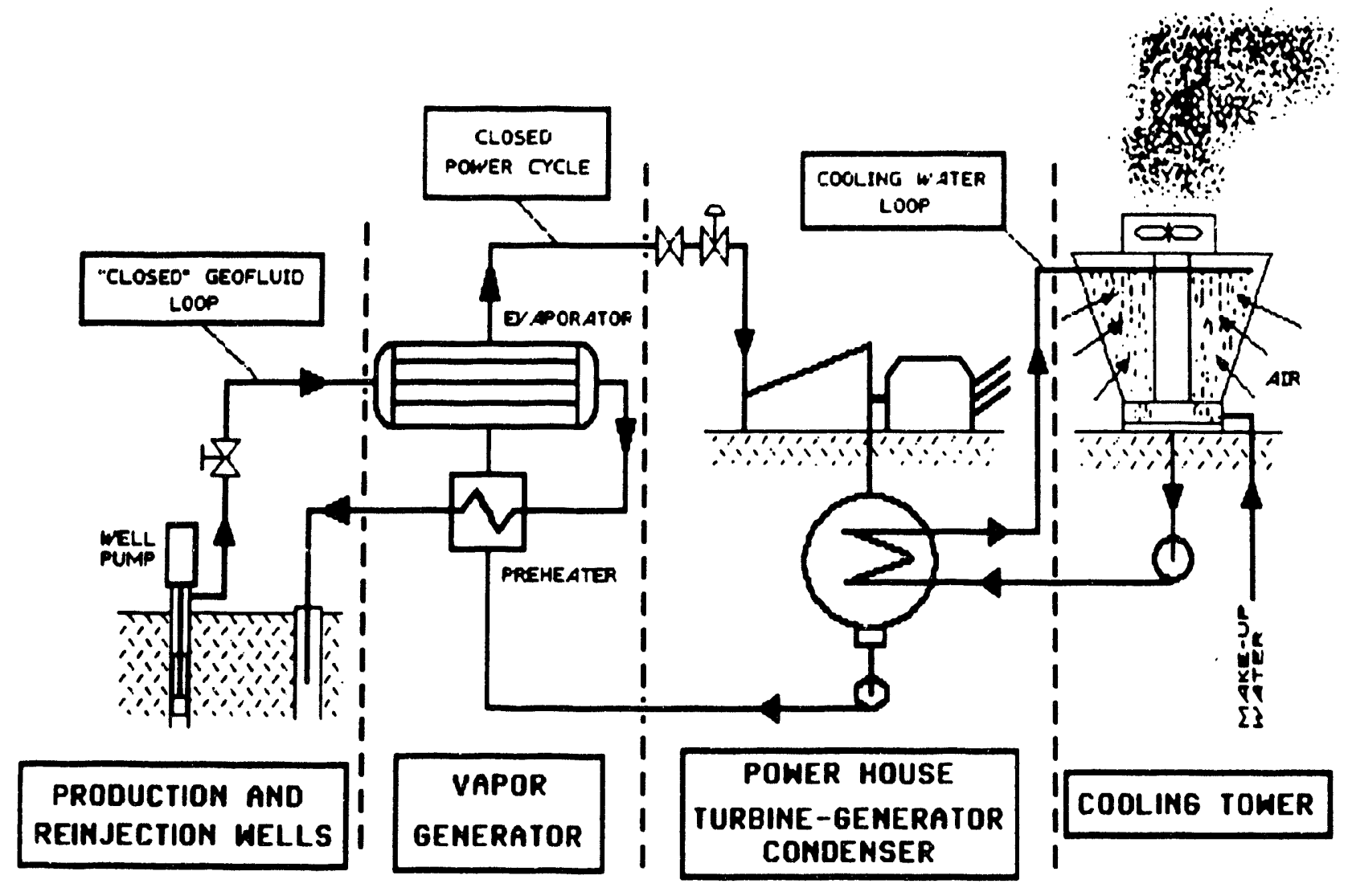

Figure A2. Simplified schematic of basic binary plant. Source: Ronald DiPippo, "Geothermal Energy: Electricity Production and Environmental Impach A Worldwide Perspective," in Energy and the Environment in the 21st Century, ed. Jefferson W. Tester, (Cambridge, MA: The MIT Press, 1991), 747.

The binary system requires a working fluid such as propane or butane. It is the most cost-effective and reliable way to convert large amounts of low temperature geothermal resources into electricity.

\section{HOT DRY ROCK}

Hot dry rock reservoirs are formed when rock is heated by magma. Little or no water is present [2]. In exploiting hot dry rock, a well is drilled to reach rock which is sufficiently hot to be useful. Water is then pumped down the well under pressures high enough to open up 
natural joints in the rock and create a manmade reservoir consisting of a relatively small amount of water dispersed in a large volume of rock. One or more wells are subsequently drilled to intercept the reservoir some distance from the first, and the system is operated by circulating pressurized water down one well (the injection well), across the reservoir, and up the other well (the production well). This scheme is shown in Figure A3.

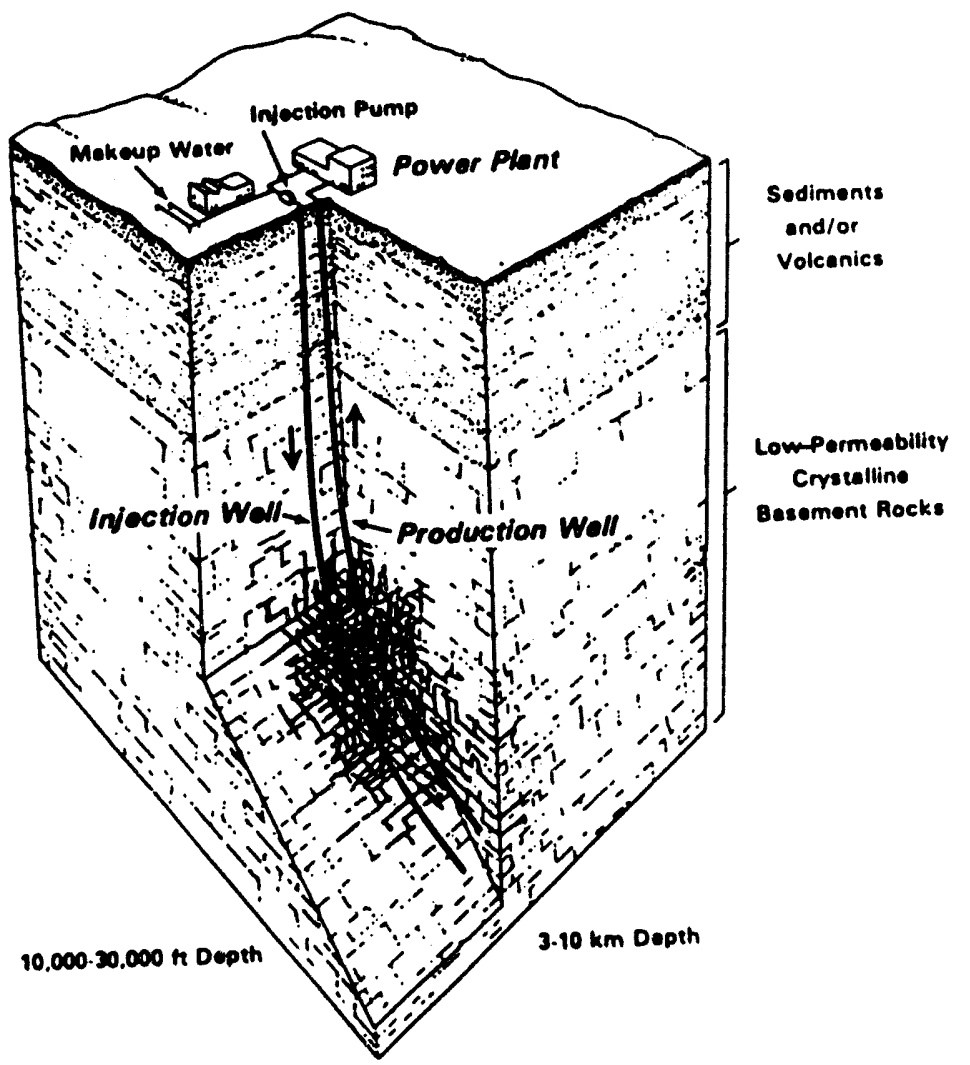

Figure A3. Hot dry rock geothermal system. Source: D. W. Brown, et al, "Hot Dry Rock Geothermal Energy-An Emerging Energy Resource with Large Worldwide Potential," in Energy and the Environment in the 21st Century, ed. Jefferson W. Tester, (Cambridge, MA: The MIT Press, 1991), 933.

As the water flows across the reservoir, it becomes heated by contact with the hot rock. At the surface, this thermal energy is extracted by a heat exchanger and the water is recirculated to repeat the process. Thus, the same water flows repeatedly around the system in a closed loop [3]. 


\section{GEOPRESSURED}

Geopressured reservoirs are deep reservoirs containing brine that is trapped in sand under layers of impermeable shale (creates very high pressures) and heated by conduction from the rocks below. The brine contains methane. These reservoirs can produce thermal energy from the hot brine, hydraulic energy from the high pressures, and methane. The economic feasibility of these reservoirs has not yet been proven and little R\&D work is underway to exploit these reservoirs. Problems exploiting geopressured reservoirs include how to work with high pressures and how to drill deep enough to tap into the reservoir.

\section{MAGMA}

Magma systems have large amounts of high-grade energy. The temperatures are extremely high, generally greater than $800^{\circ} \mathrm{C}$. The principal barrier to magma development is verification of the resource at depths that can be economically drilled. R\&D work is currently in the experimental stage. It is believed the most likely technology that will be used to exploit magma energy will rely on a drilling system which will chill, solidify, and fracture the magma. A working fluid will then be circulated for direct contact heat transfer [2]. 


\section{References}

1. Morgan, Daniel, Renewable Energy and the Environment-A Fact Sheet, CRS Report for Congress, Library of Congress, Washington, DC, January 31, 1992.

2. US Department of Energy , "Renewable Energy: An Overview," Information Brochure FS 175, Washington, DC, March 1990.

3. Duchane, David V, "Hot Dry Rock," Climate Change and Energy Policy, Proceedings of the International Conference on Global Climate Change: Its Mitigation Through Improved Production and Use of Energy, eds. Louis Rosen and Robert Glasser, Los Alamos, NM, Np, 1991. 


\section{Distribution}

MS 1033 Jim Dunn, 6111

MS 0722 Vicki Bruch, 6904 (10)

MS 9018 Central Technical Files, 8523-2

MS 0899 Technical Library, 7141 (5)

MS 0619 Technical Publications, 7151

MS 0100 Document Processing for DOE/OSTI, 7613-2 (10) 
11
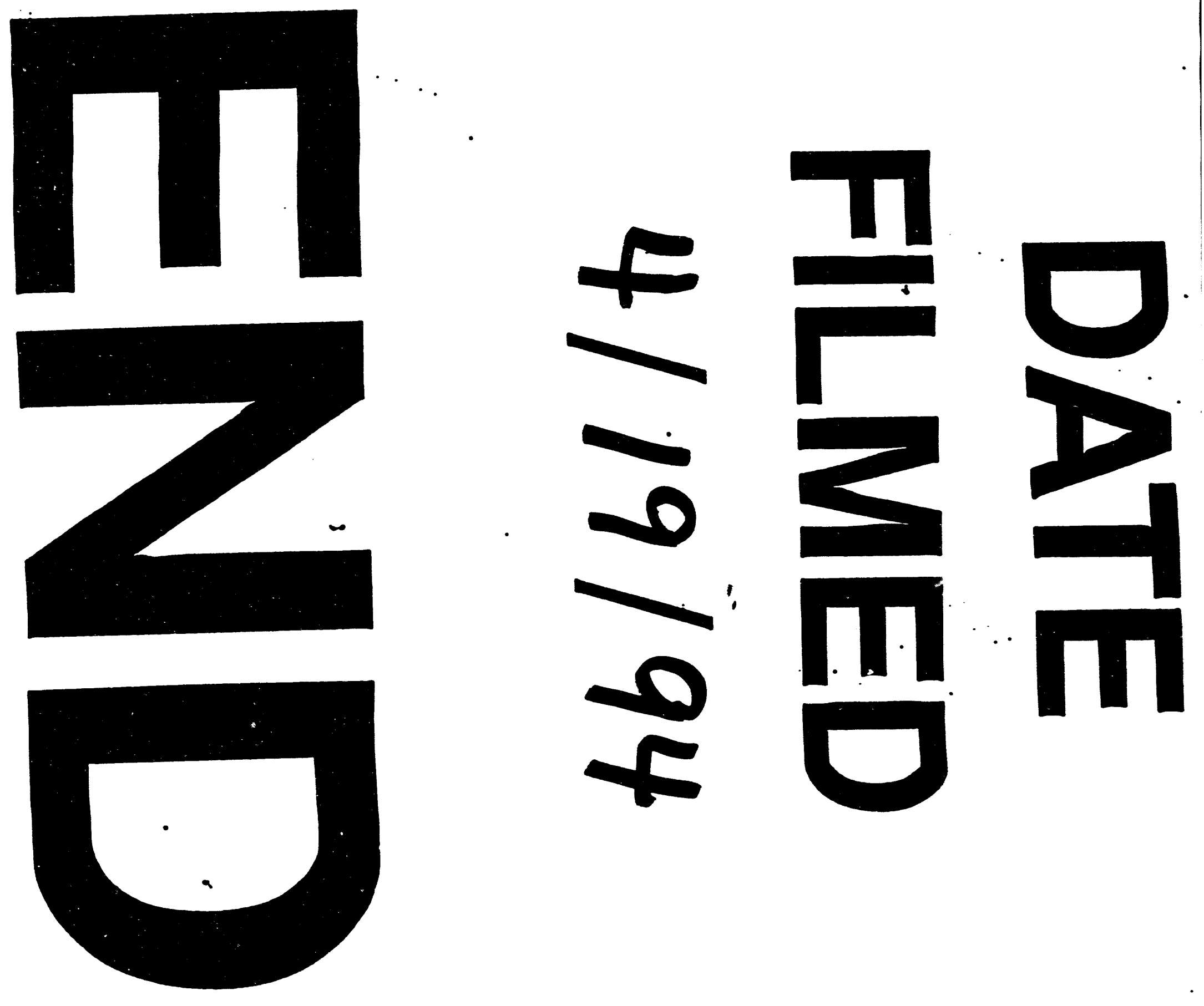
